\title{
TINJAUAN KRIMINOLOGI TERHADAP KENAKALAN REMAJA (JUVENILE DELIQUENCY) DAN PENCEGAHANNYA DITINJAU DARI UU PERLINDUNGAN ANAK
}

\author{
Oleh: \\ Lestari Victoria Sinaga ${ }^{1)}$ \\ Jhon Rico Kaban ${ }^{2)}$ \\ dan Eddy Supratman ${ }^{3)}$ \\ Universitas Darma Agung, Medan 1,2,3) \\ E-mail: \\ Missthary35@gmail.com ${ }^{1)}$ \\ Jhonrico@gmail.com $^{2)}$ \\ eddysupratman1@gmail.com ${ }^{3)}$
}

\begin{abstract}
This study aims at finding the causes influencing the emergence of juvenile delinquency, the factors driving the emergence of mass fights among adolescents, and How to deal with juvenile delinquency and mass fights between groups. This research is a normative juridical method, namely Legal Research conducted by examining library materials or secondary data. The results show that factors causing juvenile / juvenile delinquency, among others, are psychiatric or psychological factors and family structure. Mass fighting is one form of juvenile delinquency, where there are two contributing factors, namely internal factors (from within) and external factors, namely environmental factors (family, school and community). While specific factors for example to show a sense of solidarity and loyalty from friends (who tend to be inconsequential), defending the good name of the school, negative competition, lack of transportation facilities, the complexity of big city life, showing hard films on television and so on.
\end{abstract}

Keyword: Juvenile Delinguency, Child, Criminology

\section{ABSTRAK}

Penelitian ini bertujuan untuk menemukan penyebab yang mempengaruhi munculnya kenakalan remaja, faktor-faktor yang mendorong munculnya perkelahian massal di kalangan remaja, dan Bagaimana menangani kenakalan remaja dan perkelahian massal antar kelompok. Penelitian ini adalah metode yuridis normatif, yaitu Penelitian Hukum yang dilakukan dengan memeriksa bahan pustaka atau data sekunder. Hasil penelitian menunjukkan bahwa faktorfaktor yang menyebabkan kenakalan remaja / remaja antara lain faktor kejiwaan atau psikologis dan struktur keluarga. Perkelahian massal adalah salah satu bentuk kenakalan remaja, di mana ada dua faktor yang berkontribusi, yaitu faktor internal (dari dalam) dan faktor eksternal, yaitu faktor lingkungan (keluarga, sekolah dan masyarakat). Sedangkan faktor spesifik misalnya menunjukkan rasa solidaritas dan loyalitas dari teman (yang cenderung tidak penting), membela nama baik sekolah, kompetisi negatif, kurangnya fasilitas transportasi, kompleksitas kehidupan kota besar, mempertontonkan film-film keras tentang televisi dan sebagainya.

Kata kunci: Juvenile Delinguency, Anak, Kriminologi 


\section{PENDAHULUAN}

Tipe kenakalan remaja itu semakin bertambah jumlahnya dengan semakin lajunya perkembangan industrialisasi dan urbanisasi. Kenakalan remaja itu telah berkembang menjadi salah satu penyakitmasyarakat yang menimbulkan kecemasan di tengah - tengah masyarakat, karena kenakalan anak / remaja ini telah mengarah kepada tindakan kriminal.

Pendekatan moralistik ini dilaksanakan dengan menyebar luaskan ajaran-ajaran agama dan moral, yang dapat menekan nafsu untuk berbuat kejahatan.Kehidupan beragama yang sehat harus ditanamkan pada diri anak/remaja sejak dini, karena norma agama merupakan beneng yang paling kuat untuk menghindarkan timbulnya tindakantindakan delinquen. Pemahaman akan adanya dosa akan perbuatan jahat dan adanya hari pembalasan atas semua perlakuan manusia di muka bumi akan meredam keinginan untuk berbuat kejahatan dan hal ini hanya dapat diperoleh melalui kehidupan beragama.

wujud-wujud perilaku delinquen dari anak-anak muda/remaja banyak membawa meresahan dan kerugian baik bagi subjek pelaku dan terutama semakali bagi objek/korban tindakan delinquen itu. Apapun akibat yang ditimbulkannya, kenakalan remaja perlu mendapat perhatian secara khusus dan harus ditanggulangi sedini mungkin, karena akibat yang ditimbulkannya merugikan banyak pihak, baik dirinya pribadi, keluarga, masyarakat sekitarnya juga pemerintah.

Pada dasarnya upaya-upaya pencegahan atau penanggulangan kenakalan remaja dengan perkelahian massal adalah sama saja, karena perkelahian massal anatar kelompok/sekolah itu merupakan salah satu bentuk kenakalan remaja.

Adapun upaya-upaya yang dapat dilakukan untuk menanggulangi kenakalan anak/remaja tersebut melalui beberapa pendekatan atau alternatif, yaitu:

1. Pendekatan Moralistik,

2. Pendekatan Humaniter,

3. Pelaksanaan Sistem Peradilan Pidana.

ada kemungkinan bagi hakim untuk menjatuhkan pidana secara langsung, maka sebaiknya digunakan pidana bersyarat saja. Dan selama percobaan anak tersebut dapat diawasi oleh kejaksaan atau pegawai BISPA.

Menurut ahli dalam lapangan kejahatan anak-anak, kesimpulannya bahwa anak sedapat mungkin jangan dipisahkan dari orang tuanya, karena orang tuanya selalu masih didalam suasana kasih sehingga anak berkembang secara wajar dan lebih mudah menjadi baik.Akan tetapi jika keadaan keluarga sedemikian jeleknya sehingga mempengaruhi anak, baru anak tersebut dipisahkan dari orang tuanya.Dalam hal ini diserahkan kepada pemerintah.Dan kalau perkaranya sudah cukup berat, atau sebagai residivis baru dijatuhi pidana. Berdasarkan hal tersebut membuat peneliti tertarik untuk melakukan penelitian dengan rumusan Apakah penyebab yang mempengaruhi timbulnya kenakalan remaja, Apakahfaktor pendorong timbulya perkelahian massal di kalangan remaja, Bagaimana cara menanggulangi kenakalan remaja dan perkelahian massal antar kelompok

\section{TINJAUAN PUSTAKA}

Jevenile berasal dari bahasa Latin yaitu "Juvenilis", artinya anak-anak, anak muda, ciri karakteristik pada anak muda, sifat-sifat khas pada perilaku remaja.

Delinquent berasal dari bahasa Latin yaitu "Delinquere", yang berarti terabaikan, mengabaikan yang kemudian diperluas artinya menjadi jahat, asosial kriminal, pelanggaran aturan, perbuatan ribut, pengacau, pentror, tidak dapat diperbaiki lagi, durjana, dursila dan lainlain.

\begin{tabular}{lrr}
\multicolumn{2}{c}{ Delinquency itu } & selalu \\
mempunyai & konotasi & serangan, \\
pelanggaran, kejahatan dan & keganasan
\end{tabular}


yang dilakukan oleh anak-anak muda/remaja.

Fuad Hasan merumuskan juvenile deliquency adalah perbuatan anti sosial yang dilakukan oleh anak remaja bilamana dilakukan oleh orang dewasa dikualifikasikan sebagai tindak kejahatan.

Kartini Kartono, dalam bukunya "Patologi Sosial dan Kenakalan Remaja", menjabarkan pengertian jevenile deliquency ialah perilaku jahat atau dursila, atau kejahatan/kenakalan anakanak muda, merupakan gejala sakit secara sosial pada anak-anak dan remaja yang disebabkan oleh suatu bentuk pengabaian sosial, sehingga mereka mengambangkan pola tingkah laku yang menyimpang.

Paham kenakalan remaja dalam arti luas meliputi perbuatan-perbuatan anak remaja yang bertentangan dengan kaidahkaidah Hukum tertulis.baik yang terdapat dalam KUHP maupun dalam perundangundangan di luar KUHP (pidana khusus). Dapat pula terjadi perbuatan anak remaja tersebut bersifat anti sosial yang menimbulkan keresahan masyarakat pada umumnya.Selanjutnya kenakalan remaja tersebut semakin luas cakupannya dan lebih dalam bobot isinya.

Kenakalan remaja tersebut meliputi perbuatan-perbuatan yang sering menimbulkan keresahan di lingkungan masyarakat, sekolah maupun keluarga. Contoh yang sangat sederhana dalam hal ini ialah pencurian oleh anak remaja, perkelahian di kalangan anak didik yang kerap kali berkembang menjadi perkelahian antar sekolah, mengganggu wanita di jalanan, perbuatan-perbuatan lain yang tercela seperti mengisap ganja, mengedarkan pornografis, dan coret-coret tembok pagar yang tidak pada tempatnya.

\section{METODE PENELITIAN}

Metode pendekatan yang dilakukan dalam penelitian ini adalah metode yuridis normatif, yaitu Penelitian Hukum yang dilakukan dengan cara meneliti bahan pustaka atau data sekunder, bempa hukum positif dan bagaimana penerapannya dalam praktik di Indonesia.
4. HASIL dan PEMBAHASAN

a. Penyebab Timbulnya Kenakalan Remaja

Dalam kondisi statis, gejala juvenile deliquency atau kejahatan/ kenakalan remaja merupakan gejala sosial yang sebagaian dapat diamati serta diukur kuantitas dan kualita kejahatannya, namun sebagian lagi tidak bisa diamati dan tetap tersembunyi, hanya bisa dirasakan ekseseksesnya sedang dalam kodisi dinamis gejala kenakalan remaja tersebut merupakan gejala yang terus menerus berkembang, berlangsung secara progresif sejajar dengan perkembangan teknologi, industrialisasi dan urbanisasi.

Kartini Kartono, membagi kenakalan remaja berdasarkan ciri kepribadian yang defek, yang mendorong mereka menjadi delinquen. Anak-anak muda ini pada umunya bersifat pendek pikir, sangat emosional, agresir, tidak mampu mengenal nilai-nilai etis dan cenderung suka menceburkan diri ke dalam perbuatan yang berbahaya.Hati nurani mereka hampir tidak dapat digugah, beku. Tipe delinquensi menurut struktur kepribadian ini dibagi atas:

1. Delinquensi terisolir;

2. Delinquensi neurotik;

3. Delinquensi psikopatik;

4. Delinquensi defek mental.

\section{b. Faktor Yang Mempengaruhi Terjadinya Perkelahian Massal Dalam Kalangan Remaja \\ 1. Faktor Internal}

Faktor internal atau faktor endogen berlangsung lewat proses internalisasi diri yang keliru oleh anak-anak remaja dalam menanggapi lingkungan sekitarnya dan semua pengaruh dari luar. Tingkah laku mereka itu merupakan reaksi yang salah atau irasional dari proses belajar. dalam bentuk ketidakmampuan mereka dalam melakukan adaptasi terhadap lingkungan sekitar. Dengan kata lain, anak remaja itu melakukan mekanisme pelarian diri dan pebelaan diri yang salah atau tidak rasional, dalam wujud; kebiasaan 
melakukan maladaptif, agresi dan pelangaran terhadap norma-norma sosial dan hukum formal, diwujudkan dalam bentuk; kejahatan, kekerasan, kebiasaan berkelahi massal dan sebagainya.

Adapun faktor-faktor internal antara lain:

a. Reaksi Frustasi negative ada pada individu itu sendiri, berupa.

- Konflik batiniah, yaitu pertentangan antara dorongan jiwa kekanak-

kanakan melawan pertimbangan yang lebih rasional. Terjadilah kemudian banyak ketegangan jiwa dan kecemasan sehingga menghambat

dan membelokan adaptasi anak terhadap tuntutan lingkungan.

- Pemahaman dan penalaran yang keliru terhadap semua pengalaman, sehingga terjadi harapan palsu, pantasi, ilusi, kecemasan (sifatnya semu

tetapi dihayati oleh anak sebagai kenyataan). Sebagai akibatnya anak

mereaksi dengan tingkah laku yang salah berupa apatisme, putus asa, pelarian diri, agresi, mengamuk, kegila-gilaan, tindak kekerasan,

kegemaran berkelahi dan lain-iain.

- Menggunakan reaksi frustasi negatif, lewat cara-cara penyelesaianyang tidak rasional, anak mencoba membela diri dari kelemahan dan kekerdilan sendiri dengan menggunakan macam-macam alasan, reaksi dan perilaku yang tidak wajar.

- Gangguan pengamatan dan tanggapan pada anak-anak remaja

Adapun kedua gangguan di atas sangat mengganggu daya adaptasi dan perkembangan pribadi anak yang sehat Gangguan pengamatan dan tanggapan itu antara lain berupa ilusi, halusinasi, dan gambaran semu.
Tanggapan anak tidak merupakan pencerminan realita lingkungan yang nyata, tetapi berupa pengolahan batin yag keliru, sehingga timbul interpretasi dan pengertian yang salah sama sekali. sebabnya ialah semua itu diwarnai harapan yang terlalu muluk dan kecernasan yang berlebihan, dunia dan masyarakat tampak mengerikan dan mengandung bahaya laten di mata anak. Sebagai akibat jauhnya, anak-anak menjadi agresif dan eksplosif, dalam menghadapi segala macam "tekanan dan bahaya dari luar" karena itu reaksinya adalah cepat naik darah, cepat bertinak menyerang dan berkelahi.

Gangguan berpikir dan intelagensi pada diri remaja.Anak yang sehat pasti mampu membetulkan kekeliruan sendiri dengan jalan berpikir logis dan mampu membedakan pantasi dari kenyataan, sebaliknya anak yang terganggu jiwanya akan memperalat pikirannya sendiri untuk membela dan membenarkan gambarangambaran semu dan tanggapan yang salah. Akibatnya, reaksi dan tingkah laku anak menjadi salah kaprah, menjadi liar dan tidak terkendali, selalu memakai cara-cara yang keras dan perkelahian dalam menanggapi segala kejadian.

Intelegensi dan kecerdasan dapat diartikan sebagai kemampuan untuk menggunakan secara tepat, cermat, efisien alat-alat bantu berpikir guna memecahkan masalah dan adaptasi diri terhadap tuntutan-tuntutan baru. Maka intelegensi bisa diartikan pula sebagai potensi mawas diri/mawas situasi dengan cepat dan cermat.

\section{Faktor Eksternal}

Keluarga adalah faktor pertama dan utama dalam melaksanakan proses sosialisasi dan sivilisasi pribadi anak. Di tengah keluarga anak belajar mengenal makna cinta kasih, simpati, loyalitas, idiologi, bimbingan dan pendidikan, keluarga memberikan pengaruh yang menentukan pada pembentukan watak kepribadian anak, dan menjadi unit kesatuan terkecil yang memberikan 
pondasi primer bagi perkembangan anak, baik buruknya struktur keluarga mamberikan dampak baik dan buruknya perkembangan jiwa dan jasmani anak.

Bila rumah tangga terus menerus dipenuhi dengan konplik, menjadi retak dan akhirnya mengalami perceraian maka mulailah serentetan kesulitan bagi semua anggota keluarga, terutama anak-anak. Pecahlah harmoni dan keluarga dan anak menjadi sangat bingung dan merasakan ketidakpastian emosional.Dengan perasaan cemas, marah dan risau anak mengikuti pertengkaran antara ayah dan ibu, mereka tidak tahu harus memihak kepada siapa

Bila orang tua terlalu banyak melindungi dan memanjakan anak-anaknya dan menghindarkan mereka dari berbagai kesulitan dan meninjau hidup yang kecil, anak-anak pasti akan menjadi rapuh dan tidak akan sanggup mandiri, mereka akan selalu bergantung pada orang tua, merasa cemas dan bimbang ragu, aspirasi dan harga dirinya tidak bisa tumbuh

Penolakan orang tua.Ada perasaan suami istri yang tidak pernah bisa memikul tanggung jawab sebagai ayah dan ibu.Mereka masih ingin melakukan kebiasaan hidup yang lama, bersenangsenang sendiri seperti sebelum menikah atau masingmasing tengelam dengan kesibukannya dan pekerjaannya tanpa memperhatikan dan memenuhi tanggung jawab sebagai orang tua.

Pengaruh buruk dari orang tua, Tingkah laku kriminal, a-sosial dari orang tua atau salah satu anggota keluarga bisa memberikan pengaruh menular kepada anak.Anak menjadi ikut-ikutan menjadi kriminal dan menjadi asusila atau anti sosial.Dengan begitu kebiasaan buruk orang tua mengkandisonir tingkah laku dan sikap anak-anaknya.

Wujud perilaku delinquen ini adalah.

1. Kebut-kebutan di jalan dengan mengganggu ketertiban lalu lintas, dan membahayakan jiwa sendiri serta orang lain.
2. Perilaku ugal-ugalan, berandalan, urakan, yang mengacaukanketentraman lingkungan sekitar. Tingkah ini bersumber dari kelabihanenergi dan dorongan yang tidak terkendali serta kesukaan menterorlingkungan.

3. Perkelahian antar gang, antar kelompok, antar sekolah, sehingga kadang-kadang membawa korban jiwa.

4. Membolos sekolah lalu bergelandangan sepanjang jalan atau bersembunyi di tempat-tempat terpencil sambil melakukan eksperimen bermacam-macam kedurjanaan dan tindak asusila.

5. Kriminalitas anak-anak remaja/muda antara lain berupa perbuatan

mengacau, memeras, maling, mencuri, mencopet, merampas, menjambret, menyerang, merampok, menggarong, melakukan

pembunuhan mencekik, meracun tinfak kekerasan dan pelangaran lain.

6. Berpesta pora sambil bermabukmabukan, melakukan hubngan seks bebas, mabuk-mabukan, dan menimbulkan keadaan yang kacau balau yang mengganggu lingkungan.

7. Perkosaan, agresifitas seksualitas dan pembunuhan dengan motifseksual atau didorong reaksi-reaksi konfensatoris dari perasaandiabaikan, menuntut pengakuan diri, defresi hebat rasa kesunyian,emosi balas dendam, kekecewaan ditolak cintanya oleh wanita dan Iain-lain.

8. Kecanduan dan ketagihan bahan narkotik (obat bius) yang erat dengan tindak kejahatan.

9. Homoseksualitas dan gangguan seksual lain pada anak remaja 
disertai

tindak-tindak sadistis.

10. Perjudian dan bentuk-bentuk permainan lain dengan taruhan, sehinggamangakibatkan ekses kriminalitas.

11. Komersialitas seks, pengguguran janin oleh gadis-gadis delinquen danpembunuhan bayi oleh ibu-ibu yang tidak kawin.

12. Tindakan radikal dan ekstrim dengan kekerasan, penculikan dan

pembunuhan yang dilakukan oleh anak-anak remaja.

13. Perbuatan asosial yang disebabkan oleh gangguan-gangguan kejiwaanoleh anak-anak remaja psikopatik dan menderita gangguan-gangguanjiwa lainnya.

\section{Kenakalan Remaja dan Perkelahian Massal di Indonesia Dewasa Ini di Dalam Pandangan Hukum Nasional}

Beberapa ketentuan antara lain:

1. Menurut UU No. 23 tahun 2002 pasal 1.

2. Menurut Hukum Adat

3. Menurut KUH Perdata

4. Menurut KUH Pidana

5. Menurut UU No. 4 Tahun 1979 pasal 1.

\section{Ad.1. Menurut UU No. 23 tahun 2002}

Anak adalah seseorang yang belum berusia 18 (delapan belas) tahun, termasuk anak yang masih dalam kandungan.

\section{ad.2. Menurut Hukum Adat}

Dalam Hukun Adat tidak dikenal anak/remaja, tetapi yang dikenal adalah anak di bawah umur, yaitu mereka yang belum menunjukan tanda-tanda pisik yang kongkrit bahwa ia telah dewasa. Jadi dalam Hukum Adat, bukan umur yang menentukan seseorang telah dewasa atau belum, tetapi pisik seseorang.
Ter Haar dalam bukunya "Benginselen en Stelsel van Het Adatrecht" menyatakan:"Seseorang sudah dewasa menurut hukum adat apabila memenuhi elemen-elemen:

a. Sudah kawin,

b. Pindah dari rumah orang tua/mertua,

c. Mendirikan rumah tangga sendiri,

d. Diundang dalam upacara adat atas nama sendiri.

\section{Ad.3. Menurut KUH.Perdata}

Dalam Undang-undang ini pengertian remaja tidak dijumpai melainkan hanya membedakan antara telahdewasa dengan belum dewasa seperti terdapat dalam pasal 330 ayat $2 \mathrm{KUH}$ Perdata, yang berbunyi sebagai berikut:

"Belum dewasa adalah belum mencapai umur genap 21 tahun dan tidak terlebih dahulu kawin."

\section{ad.4. Menurut KUH.Pidana}

Menurut KUHP, berdasarkan pasal 45 KUHP, disebutkan bahwa yang dimaksud dengan anak adalah seorang yang belum berusia 16 (enam belas) tahun.

Selama persidangan

a. Sebagai pelaku

- Hak untuk mendapatkan penjelasan mengenai tata cara persidangan dan kasusnya.

- Hak mendapatkan pendamping, penesehat selama persidangan.

- Hak untuk mendapatkan fasilitas ikut serta memperlancar persidangan

mengenai dirinya (transpor, perawatan kesehatan).

- Hak untuk mendapatkan perlindungan terhadap tindakantindakan yang merugikan, menimbulkan penderitaan mental, fisik dan sosial.

- Hak untuk menyatakan pendapat.

- Hak untuk memohon ganti kerugian atas perlakukan yang menimbulkan penderitaan karena ditangkap, ditahan, dituntut ataupun 
diadili tanpa alasan yang berdasarkan undang-udang atau karena kekeliruan mengenai orangnya atau hukum menurut cara yang diatur dalam KUHAP (pasal 1 ayat 22).

- hak untuk mendapatkan perlakuan/pembinaan yang positif yang mengembangkan dirinya sebagai manusia seutuhnya.

- Hak akan persidangan tertutup demi kepentingannya

b. Sebagai korban

- hak untuk mendapatkan fasilitas untuk menghadiri sidang sebagai saksi/korban.

- Hak mendapatkan penjelasan mengenai tata cara persidangan dan

kasusnya.

- Hak untuk mendapatkan perlindungan terhadap tindakan-tindakan yang merugikan menimbulkan penderitaan mental, fisik, sosial dari siapa saja

- Hak untuk menyatakan pendapat

- Hak untuk mendapatkan ganti kerugian atas kerugian, penderitaannya.

- Hak untuk memohon persidangan tertutup.

c. Sebagai saksi

- Hak untuk mendapat fasilitas untuk menghadiri sidang sebagai saksi.

- Hak untuk mendapatkan penjelasan mengenai tata cara persidangan,

- Hak untuk mendapatkan perlindungan terhadap tindakan-tindakan yang merugikan, menimbulkan penderitaanmertal, fisik, sosial dari siapa saja.

- Hak untuk mendapatkan izi dari sekolah untuk menjadi saksi.
3. Setelah persidangan

a. Sebagai pelaku

- Hak untuk mendapatkan pembinaan dan penghukuman yang manusiawi sesuai dengan Pancasila, UUD 1945 dan ide mengenai pemasyarakatan.

- Hak untuk mendapatkan perlindungan terhadap tindakantindakan yang merugikan mental, fisik, sosial dari siapa saja.

- Hak untuk tetap berhubungan dengan orang tuanya, keluarganya.

b. Sebagai korban

- Hak mendapatkan perlindungan terhadap tindakan-tindakan yang merugikan, menimbulkan penderitaan mental, fisik, sosial dari siapa saja.

- Hak atas pelayanan di bidang mental, fisik dan sosial.

c. Sebagai saksi

- Hak untuk mendapatkan perlindungan terhadap tindakantindakan yang merugikan mental, fisik, sosial dari siapa saja.

Semua hak-hak tersebut adalah hak-hak anak yang dapat dan mereka miliki apabila anak tersebut diajukan ke depan sidang pengadilan, baik ia sebagai pelaku, korban ataupun saksi. Jadi anak mempunyai hak-hak yang dilindungi dan dijamin oleh hukum kita.Anak mempunyai kedudukan tertentu dan dilindungi oleh hukum nasional kita. Anak tidak dapat diperlakukan sewenang-wenang baik oleh orang tua ataupun oleh pihak-pihak lain.

\section{c. Beberapa Alternatif Untuk Menanggulangi Kenakalan Remaja Dan Perkelahian Massal Antar Kelompok}

Adapun upaya-upaya yang dapat dilakukan untuk menanggulangi kenakalan anak/remaja tersebut melalui beberapa pendekatan atau alternatif, yaitu: 
1. Pendekatan Moralistik,

2. Pendekatan Humaniter,

3. Pelaksanaan Sistem Peradilan Pidana.

\section{Ad. 1. Pendekatan Moralistik}

Penanggulangan kenakalan remaja dengan cara pendekatan moralistik adalah penitikberatan pada pembinaan moral dan membina kekuatan mental anak remaja. Dengan pembinaan yang baik anak remaja tidak akan mudah terjerumus kedalam perbuatan-perbuatan delinquen, sebab nilai-nilai moral tadi akan menjauhkan diri dari perbuatan-perbuatan delinquen.

Pendekatan moralistik ini dilaksanakan dengan menyebar luaskan ajaran-ajaran agama dan moral, yang dapat menekan nafsu untuk berbuat kejahatan.

\section{Ad. 2. Pendekatan Humaniter}

Pendekatan humaniter adalah pendekatan secara kemanusiaan yang diupayakan dalam usaha untuk menanggulangi kenakalan remaja dan bentuknya seperti perkelahian massal. Pemahaman dan pendekatan secara humaniter terhadap juvenile deliquency dilakukan atas dasar beberapa pertimbangan berikut:

1. Berdasarkan atas pendangan hidup dan falsafah hidup kemanusiaan/ hunianiter terhadap pribadi anakanak dan para remaja,

2. Kebutuhan akan perawatan dan perlindungan terhadap anak-anak dan

remaja yang nakal, jahat, bermasalah sosial yang disebabkan oleh

ketidakdewasaan mereka

3. Untuk menggolongkan anak dan remaja delinquen tersebut kedalam satu kategori yang berbeda dengan kategori kriminal orang dewasa,

4. Untuk menerapkan prosedurprosedur peradilan, penghukuman, penyembuhan dan rehabilitasi khusus, terutama untuk menghindarkan

anak-anak dari pengalaman traumatis yang tidak perlu, serta melindungi mereka dari tindakan manifulatif oleh orang-orang dewasa,

\section{Ad. 3 Pelaksanaan Sistim Peradilan Pidana}

Sedangkan bagi daerah yang mengikuti petunjuk atau pedoman SEM A No. 3 tahun 1959 adalag sebagai berikut:

1. Surat Edaran Mahkamah Agung No. 3 Tahun 1959 menganjurkan untuk memperlakukan penjahat anak-anak sebagai berikut:

a. perkara anak disidangkan,

- Terpisah dari orang dewasa,

- Pada hari tertentu saja,

- Oleh hakim tertentu yang ditunjuk oleh pengadilan negeri masing-masing.

b. Baik hakim, polisi dan jaksa dalam sidang ini tidak memakai toga/pakaian dinasnya.

c. Sidang selalu bersifat tertutup, wartawan tidak diperbolehkan nadir

dalam putusannya dalam sidang tertutup, publikasipun dilarang.

d. Orang tua/wali/penanggung jawab anak harus hadir agar hakim dapat mengetahui juga keadaan yang meliputi si anak, misalnya keadaan

rumah untuk dijadikan pertimbangan hakim dalam memutuskan

penempatan anak.

e. Sejak dari penyelidikan oleh pihak kepolisian telah diambil langkah pengkhususan, misalnya:

- pemeriksaan dilakukan oleh pemeriksaan sendiri terpisah dari bagian untuk orang dewasa,

- tempat penahanan terpisah dari tempat tahanan untuk orang dewasa.

f. Oleh Kejaksaan ditunjuk jaksa khusus sebagai penuntut untuk perkara anak. 
g. Dalam sidang perkara anak diikut sertakan seorang social worker (pekerja sosial) yang dulu ditangani oleh Departemen Sosial, sekarang

diserahkan kepada Bimbingan Kemasyarakatan dan Pengentasan Anak

Departemen Kehakiman.

Peranan Bimbingan Sosial dan Pengentasan Anak Untuk mengetahui apa latar belakang dari perbuatan anak tersebut melakukan perbuatan pelanggaran hukum, dalam hal ini Balai BISPA sangat memegang peranan, oleh karena sebelum hakim memeriksa seorang anak, sebaiknya riwayat anak sudah ada pada hakim yang akan memeriksanya. Peranan orang tua dalam sidang anak

- Peranan orang tua pada peradilan anak-anak, sangat dibutuhkan pada setiap persidangan, maka BISPA atau pihak kejaksaan akan menghubungi orang tua anak, untuk meminta kepada orang tuanya agar data.ig pada sidang yang telah ditetapkan.

- Dalam persidangan hakim sering menanyakan kepada orang tua anak mengapa sampai pelangaran hukum terjadi, dan bagaimana sikap orang tua terhadap anak pada hari-hari yang akan datang, apakah masih mampu untuk mendidik.

- Kalau hakim melihat bahwa orang tuanya bersungguh-sungguh mendidik

anaknya pada masa mendatang dan disamping itu pula BISPA menyarankan agar anak tersebut dikembalikan kepada orang tuanya, maka hakim tersebut akan mengembalikan anak tersebut kepada orang tuanya dengan memberikan saransaran.

- Tetapi adakalanya orang tua tidak lagi sanggup untuk mendidik anaknya

sehingga anak tersebut dijadikan anak negara melalui bantuan BISPA untuk mengirimkan anak tersebut apabila masih dibawah umur 18 tahun.

Tindakan atas hukuman percobaan.Yang dimaksud dengan hukuman percobaan adalah sebagai berikut:Bahwa selama pereodaan anak tidak boleh melakuka pelanggaran atau kejahatan. Andaikata ia masih melakukan pelangaran atau kejahatan, maka hukuman yang telah ditetapkan tersebut harus dijalani.

Anak-anak yang diberi hukuman percobaan, selain dikembalikan kepada orang tuanya ada juga yang ditempatkan pada Foster Home dengan dididik oleh Foster Parentsnya. Foster Parents adalah orang tua (keluarga asuh) yang ingin melakukan perbuatan sosial. Keluarga asuh ini mendaftarkan diri ke Departemen Sosial Direktorat Kesejahteraan Keluarga dan Anak menyatakan ingin menjadi keluarga asuh.

Selanjutnya setelah proses persidangan, pada akhirnya hakim akan menjatuhkan putusannya. Tindakan hakim tersebut adalah berdasarka pada pasalpasal KUHP yaitu pasal 45, 46, dan 47 KUHP. Seperti telah dikemukakan dalam pasal 45 ini, ada 3 (tiga) kemungkinan bagi hakim dalam menjatuhka putusannya, yaitu:

1. Memerintahkan supaya yang bersalah (anak) diserahkan kepada orang

tuanya atau pemeliharanya, tanpa pidana apapun.

2. Memerintahkan supaya yang bersalah (dalam hal ini anak) diserahkan

kepada pemerintah tanpa pidana apapun.

3. Atau menghukum anak tersebut dengan menjatuhkan pidana.

Dalam hal hakim menjatuhkan pidana, hakim berpedoman pada pasal 47 KUHP, yakni apabila:

a. Hakim menjatuhkan pidana, maka putusan pidana pokok terhadap 
perbuatan pidananya dikurangi sepertiga.

b. Perbuatan yang dilakukan merupakan kejahatan yang diancam dengan pidana mati atau pidana penjara seumur hidup, maka dijatuhkan pidana selama 15 (lima belas) tahun.

c. Pidana tambahan juga akan dikenakan maka pidana tambahan tersebut

dalam pasal 10 sub b nomor 1 dan 3 tidak dapat dikenakan.

\section{SIMPULAN dan SARAN}

\section{a. Kesimpulan}

1. Faktor yang menyebabkan timbulnya kenakalan anak/remaja,diantaranya, yaitu faktor kejiwaan atau psikis yang banyak menimbulkanbanyak konflik batin dan ketidakmampuan atau lemahnya pengendaliandiri, sehingga anak/remaja tersebut sulit untuk mengontrol dan berinteraksidengan lingkungan.Struktur keluarga yang berantakan sangat mempengaruhi perilaku jahatanak/remaja, karena keluarga adalah lingkungan terdekatnya yang membentuk dirinya sejak dini dalam proses perkembangan baik pisik maupun psikisnya.

2. Perkelahian massal merupakan salah satu bentuk kenakalan remaja, padadasarnya faktor penyebabnya juga sama, disamping faktor-faktor khususlainnya. Adapun faktor-faktor penyebab yaitu faktor internal (dari dalamdirinya) dan faktor eksternal, yaitu faktor lingkungan (keluarga, sekolahdan masyarakat). Sedangkan faktor-faktor khusus misalnya untuk menunjukan rasa solider dan setia kawan (yang cenderung ngawur), membela nama baik sekolah, persaingan yang bersifat negatif, kurangnya fasilitas angkutan, kompleksnya kehidupan kota besar, penayangan film-film keras di televisi dan sebagainya.

3. Kenakalan remaja dan perkelahian massal antar kelompok/pelajar tentu saja membawa akibat-akibat yang negatif, yang tidak hanya merugikan dirinya sendiri tetapi juga merugikan orang lain, masyarakat dan pemerintah, baik kerugian yang bersifat materil maupun moril.Kehidupan beragama perlu sekali ditanamkan kepada anak/remaja sejak dini sehingga ia mampu mengendalikan diri terhadap pengaruhpengaruh buruk disekitarnya.Ada beberapa alternatif untuk mencegah semakin meningkatnya kenakalan remaja dan perkelahian massal itu baik yang bersifat prepentif maupun represif melalui pendekatan moralistik, humaniter atau bila perlu dengan pelaksanaan sistim peradilan pidana berupa penghukuman bagi pelakunya.

\section{B. Saran}

1. Jika kita mau jujur bahwa kenakalan remaja dan perkelahian massal itu merupakan refleksi dari perbuatan orang dewasa disegala sektor kehidupan

dan merupakan proses peniruan atau identifiakasi anak/remaja terhadap segala gerak gerik dan tingkah laku orang dewasa. Oleh karena itu kita sebagai orang dewasa hendaknya mawas diri melihat kelemahan dan kekurangan diri sendiri dan melakukan koreksi terhadap kekeliruan yang sifatnya tidak mendidik dan tidak menuntun. Sebaiknya, memperbanyak kearipan, kebaikan dan keadilan, agar kita bisa dijadikan panutan bagi anakanak muda dalam perkembangannya sebagai generasi penerus kita.

2. Orang tua hendaknya dapat meningkatkan suasana kehidupan keluarga yang hangat, harmonis, penuh kasih sayang dan memupuk rasa pengertian antara sesama anggota keluarga. Orang tua juga diharapkan dapat memperhatikan perkembangan anak 
baik fisiknya maupun psikisnya, memberikan pendidikan yang baik, penanaman moral serta agama yang kuat sejak dini terhadap anak/remaja.Anak/remaja jangan dibiasakan dan dibiarkan menonton film-film yangmenayangkan adeganadegan kekerasan.Lembaga pendidikan perlu ditingkatkan kualitasnya bukan saja hanya sebagai tempat menimba ilmu tetapi juga sebagai tempat membentuk kepribadian anak/remaja.

3. Jangan pernah abaikan eksistensi atau keberadaan anak/remaja. Mereka ada dan merupakan bagian dari masyarakat kita. Jangan menganggap mereka sebagai beban yang menyulitkan dan memberatkan, sebaliknya mereka yaitu anak adaiah amanah dari Allah yang harus kita jaga, dididik, dilindungi, dicintai, didengar, diperhatikan sehingga ia merasa dirinya diterima dan dihargai sebagai pribadi yang utuh. Sebaliknya untuk para remaja, hendaknya sadar bahwa dirinya adalah aset bangsa dalam mewujudkan citacita pembangunan dan kemerdekaan, jangan mudah terpengaruh oleh hal-hal yang bersifat merusak, harus lebih selektif terhadap lingkungan dan jangan mengembangkan sikap solidaritas atau setia kawan yang cenderung ngawur dan salah arah.

\section{DAFTAR PUSTAKA}

Arrasyid, Chainur, SH., Pengantar Psikologi Kriminal. Penerbit Yani Corporation, Medan, 1988.

Gumarsa, Singgih,D., Psikologi Anak Bermasalah. Penerbit Gunung Mulia, Jakarta, 1995.

Kartono, Karakteristik Umum Remaja Nakal, 2003.
Kartono, Kartini,Patologi Sosial dan Kenakalan Remaja. Penerbit Raja wali, Jakarta, 1986.

Murni, tentang saling menghargai antar sesama anggota keluarga, 2004.

Poerwodarminto, W.J.S., Kamus Umum Bahasa Indonesia. Penerbit Balai Pustaka, Jakarta, 1984.

Rakhmat, Jallaluddin, Psikologi Komunikasi pada konsep diri, Bandung : PT Remaja Rosdakarya, 2003

Riset, Janet, Pengaruh Orang Tua, 2005.

Santrock, 1996, Faktor-faktor kecenderungan kenakalan remaja.

Sarwono, Perilaku Melanggar Aturan, 2002.

Simanjuntak, B.Drs.SH.,Latar Belakang Kenakalan Remaja, Penerbit Alumni, Bandung, 1979.

Soesilo, R., Kitab Undang-undang Hukum Pidana. Penerbit Politeia, Bogor, 1981.

Siregar, Bismar, Hukum dan Hak-hak Anak. Penerbit Yayasan LBHI dan CV Rajawali, Jakarta, 1986

Subekti, R., Kitab Undang-undang Hukum Perdata. Penerbit Pradya Paramita, Jakarta, 1981

Sudarsono, Kenakalan Remaja. Penerbit Rineka Cipta, Jakarta, 1991.

Sujanto, Agus,,Psikologi Perkembangan, Penerbit Aksara Baru, Jakarta 1981.

Suryono, M.Ashar, Remaja dan Permasalahannya, Penerbit Pustaka Antara, Jakarta, 1996 
Usman, Datuk,.,Diktat Hukum Adat. Design dan Strencilk Bina Sarana, Balai Penmas SU.

Wahyono, Agung, , Rahayu, Siti, ., Tinjauan Tentang Peradilan Anak di Indonesia. Penerbit Sinar Grafika, Jakarta 1993.

Indri Widyastuti, Afifah Wulandar, dkk, Makalah Kenakalan Remaja, SMA Muderetno Tahun Pelajaran 2010/2011

http://www.scribd.com/doc/54228613/MA KALAH-KENAKALAN-REMAJA.
Undang-undang No. 3 Tahun 2000 Tentang Perlindungan Anak

Kitab Undang-undang Hukum Perdata

Kitab undang-undang Hukum Pidana

Kitab Undang-undang Acara Pidana

\section{Website}

Anneahira, defenisi tentang kenakalan remaja, http://www.anneahira.com/narkoba/in dex.htm,

Undang-undang No. 4 Tahun 1979

Tentang Kesejahteraan Anak 